\title{
Diversity patterns of benthic bacterial communities along the salinity continuum of the Humber estuary (UK)
}

\author{
Andrea Vidal-Durà ${ }^{1, *}$, Ian T. Burke ${ }^{1}$, Robert J. G. Mortimer $^{2}{ }$ Douglas I. Stewart $^{3}$ \\ ${ }^{1}$ School of Earth and Environment, University of Leeds, Leeds LS2 9JT, UK \\ ${ }^{2}$ School of Animal, Rural and Environmental Sciences, Nottingham Trent University, Brackenhurst Campus, \\ Southwell NG25 0QF, UK \\ ${ }^{3}$ School of Civil Engineering, University of Leeds, Leeds, UK
}

\begin{abstract}
Intertidal mudflats are fluctuating environments that support highly diverse microbial communities. The highly variable physico-chemical conditions complicate the understanding of the environmental controls on diversity patterns in estuarine systems. We investigated the bacterial diversity in the surface and subsurface sediments along the salinity gradient of the Humber estuary (UK) using amplicon sequencing of the 16S rRNA gene and correlated its variations with environmental variables. The sediment depths sampled were selected based on the local resuspension patterns. In general, bacterial communities showed similar composition at the different sites and depths, with Proteobacteria being the most abundant phylum. The richness of operational taxonomic units (OTUs) was uniform along the salinity gradient. However, Hill numbers, as bacterial diversity measures, showed that the common and dominant OTUs exhibited a decreasing trend from the inner towards the outer estuary sites. Additionally, surface and subsurface bacterial communities were separated by non-metric multi-dimensional scaling (NMDS) analysis only in the mid- and outer estuary samples, where redox transitions with depth were more abrupt. Salinity, porewater ammonium concentration and acid-extractable Fe(II) in solids were the subset of environmental factors that best correlated with community dissimilarities. Analysis of regional diversity indicated that the dataset may include 2 potentially distinct communities: (1) a near-surface community that is the product of regular mixing and transport and is subjected to a wide range of salinity conditions, and (2) a bacterial community indigenous to the more reducing subsurface sediments of the mudflats of the mid- and outer estuary.
\end{abstract}

KEY WORDS: Microbial diversity - Hill numbers - Intertidal sediments - Salinity gradient · 16S rRNA · Illumina MiSeq sequencing

\section{INTRODUCTION}

Estuaries are transitional environments where substantial physico-chemical and biological gradients from freshwater to marine environments develop (Attrill \& Rundle 2002, Crump et al. 2004, Elliott \& Whitfield 2011, Lallias et al. 2015). The continuous mixing of water and sediments leads to high variability in the local physico-chemical characteristics (e.g. $\mathrm{pH}$, temperature, salinity, particle size, turbidity,

${ }^{*}$ Corresponding author: andrea.vidal@uab.cat sulfate concentration, organic matter, light exposure and river flow seasonal fluctuations), which can affect the stability and composition of microbial communities along the estuarine continuum (Crump et al. 1999, O'Sullivan et al. 2013, Liu et al. 2014, Wei et al. 2016). Although it is widely accepted that microbial communities are sensitive to salinity variations (e.g. Lozupone \& Knight 2007), no consensus on other physico-chemical factors controlling microbial abundance in estuarine systems has yet emerged

(C) The authors 2018. Open Access under Creative Commons by Attribution Licence. Use, distribution and reproduction are unrestricted. Authors and original publication must be credited. 
(Elliott \& Whitfield 2011, Telesh et al. 2013). Marine coastal sediments host very abundant and diverse microbial communities, and, although these communities play a key role in estuarine biogeochemical processes (Federle et al. 1983, Zinger et al. 2011, Reed \& Martiny 2013), the relationship between microbial composition and ecosystem functioning remains unclear (Bertics \& Ziebis 2009, Reed \& Martiny 2013). Quantifying the microbial community variations along estuarine gradients will improve our understanding of their role in these ecosystems and their response to environmental change (Reed \& Martiny 2013, Bier et al. 2015).

Salinity is a major abiotic factor controlling the patterns of benthic and pelagic diversity in estuaries (Crump et al. 1999, 2004, Attrill 2002, Lozupone \& Knight 2007, Elliott \& Whitfield 2011, Herlemann et al. 2011, Telesh et al. 2011, Campbell \& Kirchman 2013, L. Zhang et al. 2014, Lallias et al. 2015). The variation of macrozoobenthos in estuaries has been traditionally explained using the conceptual model known as Remane's concept (Remane 1934) (Fig. 1), which was developed for the non-tidal Baltic Sea and models species richness along a salinity gradient. It concludes that there is a relationship between species diversity and salinity. Species diversity reaches a minimum ('Artenminimum') in the region of 5-8 salinity ('critical salinity zone' sensu Khlebovich 1968), which can be explained by the decline in the number of non-tolerant species (marine and freshwater specialists) in the transitional waters (Elliott \& Whitfield 2011). However, despite several modifications (Schubert et al. 2011, Telesh et al. 2011, Whitfield et al. 2012) and critiques (Barnes 1989, Bulger et al. 1993, Attrill 2002, Attrill \& Rundle 2002), Remane's model has significant limitations as a description of diversity in estuarine systems. Telesh et al. (2011) conducted a meta-analysis of large datasets from previous studies in the Baltic Sea and found that protists showed a diversity maximum in the 'critical salinity zone' (Fig. 1). Subsequently, Telesh et al. (2013) proposed that salinity stress may create niches in brackish waters where there is less competition for resources, so these niches can be occupied by highly adaptable unicellular organisms (i.e. planktonic organisms). However, Herlemann et al. (2011) found that the diversity of pelagic bacteria exhibited a different pattern to protists and displayed a steady distribution in the Baltic Sea with no trend with salinity (Fig. 1), possibly due to the mixing of freshwater and marine communities.

In tidal estuaries, the impacts of large salinity variations on pelagic microbial community composition, activity and diversity have been well investigated (Feng et al. 2009, Campbell \& Kirchman 2013, Liu et al. 2014, Wei et al. 2016). However, the corresponding impacts on benthic communities have received much less attention (Klier et al. 2018). Benthic microbial communities will experience different environmental stresses to pelagic organisms and may be expected to exhibit higher bacterial biomass, higher richness and different diversity patterns (Zinger et al. 2011). For example, vertical stratification of sediment geochemistry influences the composition and function of benthic microbial communities (Musat et al. 2006, Canfield \& Thamdrup 2009, O'Sullivan et al. 2013, Liu et al. 2014, Lavergne et al. 2017). Nevertheless, sediments in tidal estuaries are frequently dis-

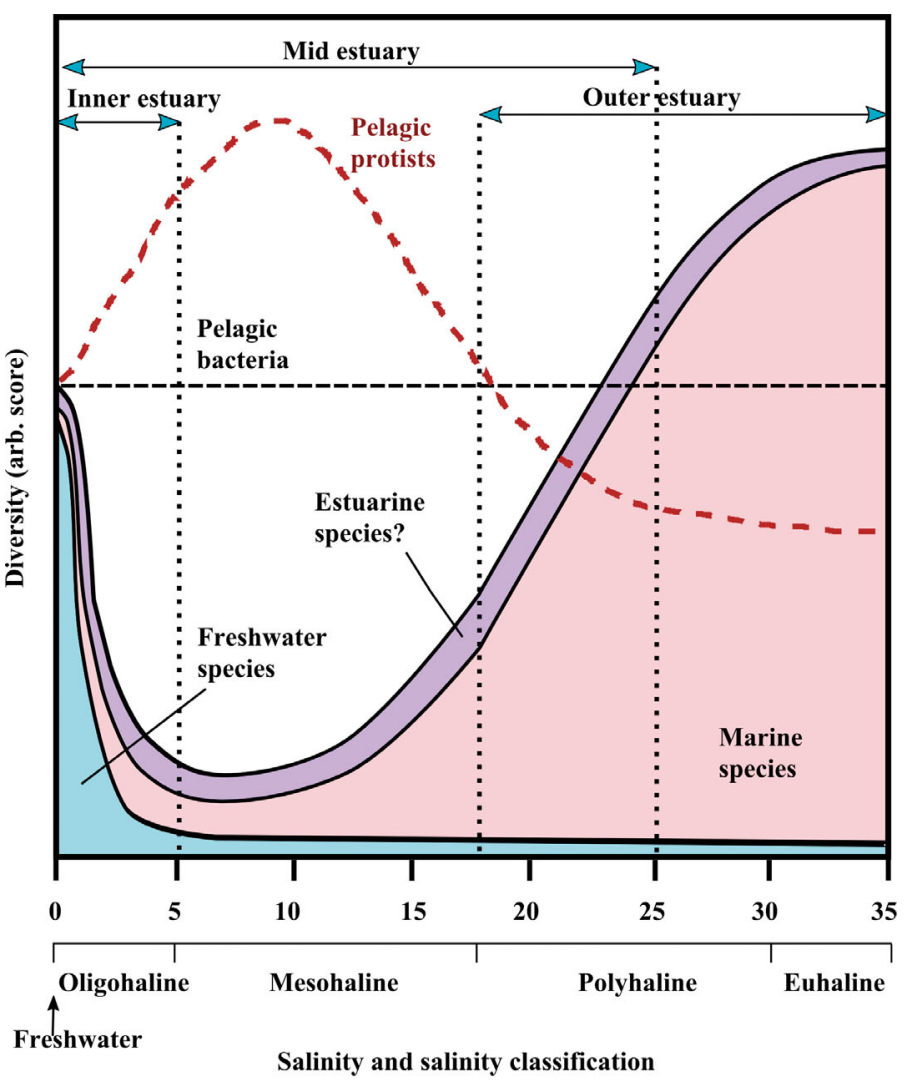

Fig. 1. Diversity variation patterns along a salinity gradient. Coloured areas represent Remane's (1934) conceptual model for the variation in macrobenthic biodiversity (after Whitfield et al. 2012, Skarlato \& Telesh 2017). Variations in the diversity of pelagic protists (Telesh et al. 2011) and planktonic bacteria (Herlemann et al. 2011) are shown as dashed lines (red and black, respectively). The dotted lines indicate boundaries for the salinity zonation defined for the Humber estuary (see 'Materials and methods') 
turbed and thus may not exhibit clear links between geochemical zones and the bacterial communities present, particularly since geochemical profiles tend to re-establish more quickly than diversity profiles within the sediments (O'Sullivan et al. 2013). Moreover, sediment resuspension facilitates the interaction and mixing of microbial assemblages between water and shallow sediments (Crump et al. 1999, Hewson et al. 2007, Feng et al. 2009). Consequently, sediment dynamics may also be an important environmental factor shaping estuarine microbial diversity.

Recently, high-throughput sequencing techniques have become widely available (Buttigieg \& Ramette 2014, Liu et al. 2014, Bier et al. 2015). These techniques offer an opportunity to investigate microbial communities in more depth. However, challenges remain as the very large datasets produced reveal the extremely diverse nature of microbiota, which is difficult to evaluate rigorously with the traditional mathematical and statistical approaches to biodiversity estimation (Buttigieg \& Ramette 2014, Oulas et al. 2015, Kang et al. 2016). Hill numbers $\left(D_{q}\right)$ are a unified and index-independent diversity concept; they were developed by Hill (1973) and were reintroduced to ecologists by Jost (2006, 2007). They have been proposed as a unified framework for measuring bacterial diversity in order to control the variability associated with rare taxa, sampling issues and other biases associated with experimental procedures (Chao et al. 2014, Kang et al. 2016).

Our general aims were to (1) describe the bacterial communities in estuarine sediments at centimetrescale resolution, (2) identify microbial diversity trends along the salinity gradient and (3) investigate how the environmental variables control such trends. As a first approach, we studied in detail 4 stations along a salinity gradient in the Humber estuary (UK) which, until now, had been sampled only once at low tide during summer. We have extensively studied the Humber Estuary in the past, observing that only the top few mm of the sediments are resuspended during regular tidal cycles, while the entire top $10 \mathrm{~cm}$ of sediment were only resuspended during a powerful storm (Mortimer et al. 1999a,b). The current sampling strategy was based on these earlier observations. Hence, samples were collected at 2 depths: surface sediments that are frequency mobilised during the tidal cycle and subsurface sediments that are only resuspended by seasonal storms, which occur once or twice a year in the Humber (House et al. 1997, Mortimer et al. 1999b). Sequencing data from amplicon sequences of the V4 hyper-variable region of the 16S rRNA gene were processed, and the benthic bacterial community composition was correlated with geochemical data using multivariate statistics to infer the environmental drivers controlling microbial diversity patterns and test whether sediment depth has an impact on microbial diversity.

\section{MATERIALS AND METHODS}

\section{Field sites and sample collection}

The Humber estuary (UK) is a highly turbid and shallow well-mixed macrotidal estuary situated on the east coast of northern England and drains an urbanised catchment with an industrial and mining heritage (Fig. 2). Its catchment area is $24240 \mathrm{~km}^{2}$

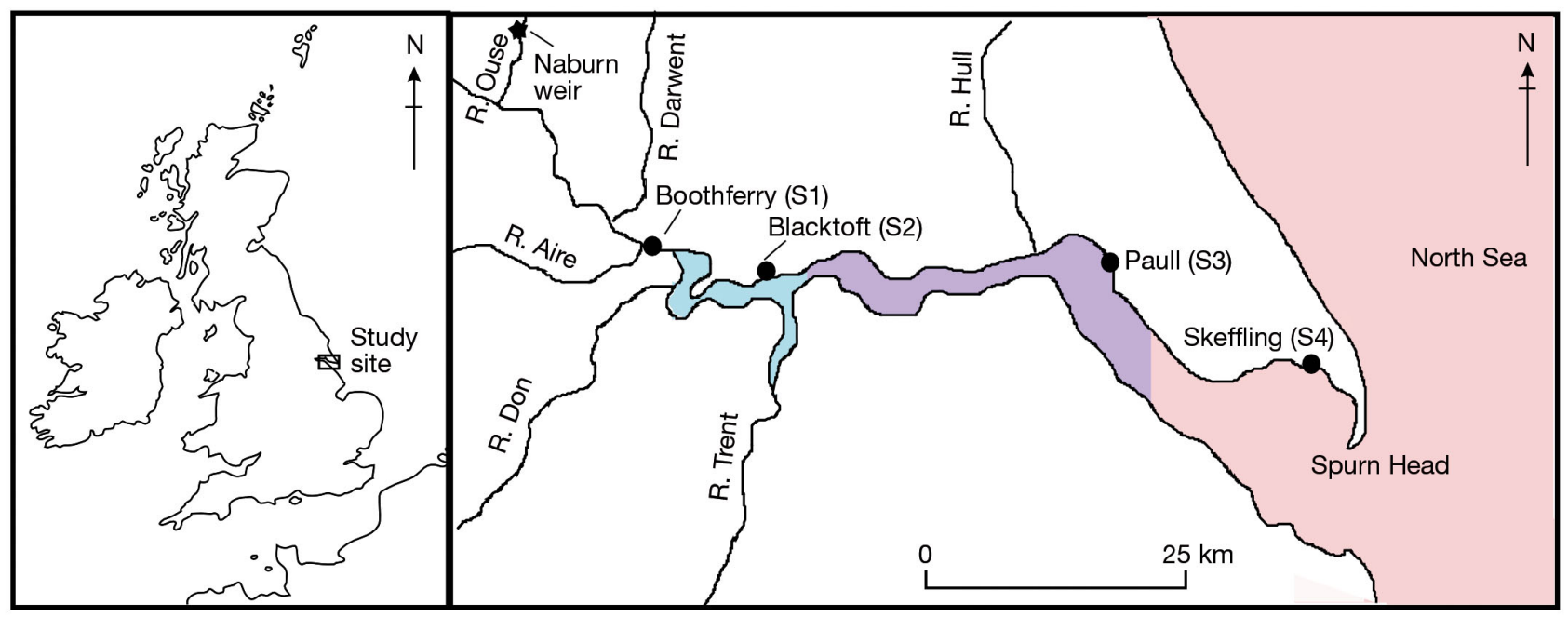

Fig. 2. Humber Estuary (UK) with the sampling sites (S1: Boothferry, S2: Blacktoft, S3: Paull and S4: Skeffling) and the salinity variation zones (blue: $\leq 5$, inner estuary; purple: 0-25, mid-estuary; pink: 18-35, outer estuary) 
(20\% of the area of England), it has $150 \mathrm{~km}^{2}$ of mudflats, and the region of freshwater-saltwater mixing stretches from Naburn weir on the Ouse, and Cromwell Weir on the Trent, to the mouth of the estuary at Spurn Head. The Humber represents the main UK freshwater input to the North Sea. Generally, the estuarine turbidity maximum is situated at the inner estuary, although it moves seasonally with the river flow (Uncles et al. 1999). Water column salinity records from 14 locations on the Humber over a period of $\sim 25$ yr have been collated to better delimit the salinity variation along the estuary and to provide a proxy for the salinity range experienced by surficial sediments (see Supplement 1 at www.int-res.com/articles/suppl/a081p277 _supp.pdf). Three salinity zones can be empirically identified. Firstly, the inner estuary extends from 0 to $60 \mathrm{~km}$ below Naburn weir (the tidal limit of the Ouse system) where the water column salinity is always $\leq 5$ (from freshwater to oligohaline water) (blue area in Fig. 2; see also annotation in Fig. 1). Secondly, the mid-estuary extends from 60 to $100 \mathrm{~km}$ downstream of Naburn weir. In this zone, the water column salinity ranges between 0 and $\sim 25$ (purple area in Fig. 2; see also annotation in Fig. 1), which includes oligohaline, mesohaline and polyhaline waters. Finally, the outer estuary extends from $100 \mathrm{~km}$ below Naburn weir to open coastal waters. Here the water column salinity typically varies from $\sim 18$ to seawater salinity (pink area in Fig. 2; see also annotation in Fig. 1), which includes polyhaline to euhaline waters.

Sediment samples were collected at low tide from the intertidal mudflats along a $65 \mathrm{~km}$ transect in the north bank of the Humber estuary during the same tidal cycle on 15 July 2014. The 4 sites were at Boothferry (S1), Blacktoft (S2), Paull (S3) and Skeffling (S4), and they were selected to span the salinity range. A sample of the surface $(\mathrm{s})(0-1 \mathrm{~cm})$ and subsurface $(d)(5-10 \mathrm{~cm})$ sediment was recovered from each location in $1 \mathrm{l}$ acid-washed containers and transported back in the dark to the laboratory. Subsamples of the homogenised sediment were stored in $2 \mathrm{ml}$ microcentrifuge tubes at $-20^{\circ} \mathrm{C}$ for subsequent DNA extraction.

\section{Physical and chemical analysis of water and sediments}

Water $\mathrm{pH}$, conductivity and temperature were determined in situ using a Myron Ultrameter PsiII handheld multimeter. Water samples from each site were collected with a bucket and transferred into 21 acid-washed polythene containers. Porewater was recovered from sediment subsamples by centrifugation $(30 \mathrm{~min}, 6000 \times \mathrm{g}$ ) in the laboratory. All water and porewater samples were filtered $(0.2 \mu \mathrm{m}$ Minisart ${ }^{\circledR}$ ) and stored at 4 or $-20^{\circ} \mathrm{C}$, as appropriate, for further analysis. Nutrient concentrations were determined by ion chromatography (sulfate and chloride) on a Dionex CD20, and colorimetrically (nitrate, nitrite and ammonium) on a continuous segmented flow analyser (SEAL AutoAnalyser $3 \mathrm{HR}$ ). Dissolved $\mathrm{Mn}$ and $\mathrm{Fe}$ were determined after acidification with $1 \%$ AnalaR $\mathrm{HNO}_{3}$ (VWR) using ion coupled plasmamass spectroscopy (Thermo Scientific ${ }^{\mathrm{TM}}$ ICP-MS). Wet sediments were analysed for particle size by laser diffraction on a Malvern Mastersizer 2000E and for $0.5 \mathrm{~N} \mathrm{HCl}$-extractable iron followed by ferrozine assay (Lovley \& Phillips 1987, Viollier et al. 2000). Acid volatile sulfide (AVS) (Canfield et al. 1986) and pyrite (Fossing \& Jørgensen 1989) were extracted from freeze-dried sediments and quantified by weight. Finally, subsamples of ground and oven-dried sediments $\left(60^{\circ} \mathrm{C}\right)$ were acid-washed with $\mathrm{HCl} 10 \%$ (v/v) prior to the total organic carbon (TOC) analysis by combustion with non-dispersive infrared detection on a LECO SC-144DR Sulfur and Carbon Analyser. All physico-chemical analyses of sediment and water samples were carried out in triplicate.

\section{DNA extraction, amplicon sequencing and sequence analyses}

DNA was extracted from environmental samples ( $~ 0.5 \mathrm{~g}$ of wet sediment) using the FastDNA ${ }^{\mathrm{TM}}$ SPIN Kit for Soil DNA Extraction (MP Biomedicals). To purify and isolate the DNA fragments larger than $3 \mathrm{~kb}$, agarose gel electrophoresis was run. The $1 \%$ agarose ' $1 x$ ' Tris-borate-EDTA (TBE) gel was stained with ethidium bromide for viewing under UV light (10× TBE solution, Invitrogen). DNA was extracted from the gel using the QIAquick gel extraction kit (Qiagen); final elution was by $1 / 10$ strength elution buffer. DNA concentration was quantified fluorometrically using the Qubit dsDNA HS Assay kit (Thermo Fisher Scientific). The manufacturer's protocols supplied with the above kits were all followed precisely.

DNA samples ( $1 \mathrm{ng}^{-1} \mathrm{l}^{-1}$ in $20 \mu \mathrm{l}$ aqueous solution) were sent for sequencing at the Centre for Genomic Research (CGR), University of Liverpool, where Illumina adapters and barcodes were attached to DNA fragments in a 2-step PCR amplification that targets the hyper-variable V4 region of the 16S rRNA gene. 
The protocol was based on Caporaso et al. (2011) and uses the forward target-specific primer 5'-GTG CCA GCM GCC GCG GTA A-3' (F515, Turner et al. 1999) and the reverse target-specific primer 5'-GGA CTA CHV GGG TWT CTA AT-3' (R806, Caporaso et al. 2011). Pooled amplicons were paired-end sequenced on the Illumina MiSeq platform $(2 \times 250 \mathrm{bp})$ generating $\sim 12 \mathrm{M}$ paired-end reads. The raw fastq files were trimmed for the presence of Illumina adapter sequences using Cutadapt version 1.2.1 (Martin 2011) by the CGR. The option -O 3 was used, so the 3' end of any reads which match the adapter sequence for $3 \mathrm{bp}$ or more were trimmed. The reads were further trimmed using Sickle version 1.200 with a minimum window quality score of 20. Reads shorter than $10 \mathrm{bp}$ were removed after trimming. If only one of a read pair passed this filter, it was included in the $\mathrm{R} 0$ file. The trimmed reads were processed using the UPARSE pipeline (Edgar 2013) within the USEARCH software package (version 8.1.1861) (Edgar 2010) installed on a Linux OS platform. First, overlapping paired-end reads were assembled using the fastq_mergepairs command. The reads from each sample were then qualityfiltered using the fastq_filter command (expected error cutoff was set at 1.0 and length truncation was not applied), re-labelled and de-replicated before they were randomly subsampled (500000 pairedend reads with an average length of $296 \mathrm{bp}$ ) to produce a manageable sample size for combined analysis ( 4 M reads). After further de-replication of the combined pool of reads, clustering and chimera filtering was performed simultaneously within the pipeline by using the cluster_otus command (with the minsize 2 option to specify a minimum abundance of 2 and discard singletons). The sequence identity threshold was fixed at $97 \%$ to define operational taxonomic units (OTUs). The utax command was applied for taxonomic assignment using the RDP 16S rRNA training database (RDP15) and a confidence value of 0.7 to give a reasonable tradeoff between sensitivity and error rate in the taxonomy prediction. The entire dataset $(\sim 6 \mathrm{M}$ pairedend reads) was then allocated to the OTUs using the usearch_global command, and the results were reported in an OTU-table. OTUs which were not classified to the bacterial phylum level with a confidence $>0.7$, or were classified as Archaea, were not included in the diversity and statistical analyses. Sequence reads are available at the National Center for Biotechnology Information (NCBI) under the Sequence Read Archive (SRA) accession number SPR105158.

\section{Statistical analyses}

Hill numbers, $D_{q}$, (Hill 1973) were used to evaluate the bacterial diversity. $D_{q}$ are a unified family of diversity indices that compensate for the disproportionate impact of rare taxa by weighting taxa based on abundance. Hence, they are more suitable for working with the large datasets produced by amplicon sequencing technologies (Kang et al. 2016). The basic expression for the Hill number is represented as:

$$
D_{q}=\left(\sum_{i=1}^{S} p_{i}^{q}\right)^{\frac{1}{1-q}}
$$

where $S$ is the total number of species (OTUs in this study), and $p_{i}$ is the proportion of individuals belonging to the $i^{\text {th }}$ species in the dataset. The degree of weighting is controlled by the index $q$ (increasing $q$ places progressively more weight on the highabundance species in a population and discounts rare species) (Hill 1973, Jost 2006, 2007, Chao et al. 2014, Kang et al. 2016). All Hill numbers are in units of 'species' (OTUs). Three Hill numbers were used to evaluate the alpha-diversity $\left(D_{q}^{\alpha}\right)$ of each individual sample: $D_{0}{ }^{\alpha}$ (species richness), $D_{1}{ }^{\alpha}$ (common species) and $D_{2}{ }^{\alpha}$ (dominant species) (Jost 2006, 2007). Traditional diversity indices, such as Shannon entropy or Gini-Simpson concentrations, can be converted to $D_{1}{ }^{\alpha}$ and $D_{2}{ }^{\alpha}$ by simple algebraic transformations (see Table S5 in Supplement 3). The assemblage or regional OTU diversity (gamma diversity, $D_{1}^{\gamma}$ ) was calculated using the combined dataset. The beta diversity, $D_{1}{ }^{\beta}$, which reflects the proportion of regional diversity contained in a single average community, was calculated from the gamma diversity and the statistically weighed alpha diversity $\left({ }^{*} D_{1}{ }^{\alpha}\right)$, using the Whittaker multiplicative law $\left({ }^{*} D_{1}^{\alpha} \times D_{1}{ }^{\beta}=D_{1}^{\gamma}\right.$ ) (Whittaker 1972). ${ }^{*} D_{1}{ }^{\alpha}$ compensates for unequal sample sizes, so is not the arithmetic average of the alpha diversities of the individual samples (see Supplement 3).

All statistical analyses were performed in RStudio ( $\mathrm{R}$ version 3.4.2) (RStudio Team 2015) using the 'vegan' package (Oksanen et al. 2013). The microbial community data were input as a matrix of the relative abundance of each OTU in each of the 8 samples. Non-metric multi-dimensional scaling (NMDS) analysis (distances based on Bray Curtis dissimilarity index) was used to graphically represent the similarity between bacterial assemblages in a 2-dimensional space. Non-parametric multivariate analysis of variance (PERMANOVA) (Anderson 2001) was used to assess the similarity in the microbial abundance among groups of samples (samples were grouped by depth, zone of the estuary and/or 
sampling location, 999 permutations). BIOENV ('biota-environment') analysis (Clarke \& Ainsworth 1993) was also performed to further investigate the relationship between the microbial populations and the environmental variables using Spearman's rank correlation coefficient and Bray Curtis dissimilarities. This test finds the combination of environmental variables that best explain the patterns in the biological data. The Mantel test was performed to study the significance of the BIOENV results. The environmental data used for the BIOENV analysis included: salinity; ammonium, nitrate, sulfate, iron and manganese porewater concentrations; TOC content; pyrite and total iron in solids; percentage of acid extractable Fe(II) in solids; iron associated with pyrite; and particle size.

\section{RESULTS}

\section{Environmental characterisation of the samples}

The environmental characterisation of the water, porewater and sediment samples is shown in Table 1. The water column salinity at the sampling locations spanned from very low salinity at the freshwater end ( 0.4 at $\mathrm{S} 1)$ to high salinity water at the sea end of the estuary (26.1 at S4). Porewater salinity was slightly lower than the water column salinity at all sites with the exception of S4. Nitrate concentration in the water column decreased along the estuary, while ammonium concentration increased slightly. With the exception of $\mathrm{S} 4_{\mathrm{s}}$, nitrate concentrations in the porewater were lower than

Table 1. Physico-chemical properties of the water column, sediment porewater and sediment at the study sites (S1-S4; see Fig. 2). Suffixes 's' and 'd' refer to surface and subsurface sediments, respectively. Particle grain size is expressed as the upper bound diameter of $50 \%$ of cumulative percentage of particles by volume $\left(D_{50}\right)$. AVS: acid volatile sulfide; TOC: total organic carbon; TS: total sulfur. Where shown, \pm values are SD. DL: detection limit; nd: not detected

\begin{tabular}{|c|c|c|c|c|c|c|c|c|}
\hline & $\mathrm{S} 1$ & & $\mathrm{~S} 2$ & & S3 & & $\mathrm{S} 4$ & \\
\hline Salinity & 0.4 & & 3.5 & & 21.6 & & 26.1 & \\
\hline $\mathrm{pH}$ & 7.87 & & 7.52 & & 7.90 & & 8.02 & \\
\hline $\mathrm{Eh}(\mathrm{mV})$ & $+151 \pm 24$ & & $+109 \pm 23$ & & $+75 \pm 8$ & & $+75 \pm 4$ & \\
\hline Temperature $\left({ }^{\circ} \mathrm{C}\right)$ & 20.0 & & 19.7 & & 19.2 & & 19.5 & \\
\hline Conductivity $\left(\mathrm{mS} \mathrm{cm}^{-1}\right)$ & 0.7383 & & 5.731 & & 30.48 & & 36.42 & \\
\hline $\mathrm{NO}_{3}^{-}(\mu \mathrm{M})$ & 266 & & 250 & & 248 & & 24 & \\
\hline $\mathrm{NO}_{2}^{-}(\mu \mathrm{M})$ & 1.6 & & 1.6 & & 0.4 & & 0.7 & \\
\hline $\mathrm{NH}_{4}^{+}(\mu \mathrm{M})$ & 7 & & 7 & & 12 & & 23 & \\
\hline $\mathrm{SO}_{4}^{2-}(\mathrm{mM})$ & 1 & & 3 & & 16 & & 22 & \\
\hline \multirow[t]{2}{*}{$\mathrm{Cl}^{-}(\mathrm{mM})$} & 2 & & 38 & & 306 & & 443 & \\
\hline & $\mathrm{S} 1_{\mathrm{s}}$ & $\mathrm{S} 1_{\mathrm{d}}$ & $\mathrm{S} 2_{\mathrm{s}}$ & $\begin{array}{l}\mathrm{S} 2_{\mathrm{d}} \\
\end{array}$ & $\begin{array}{l}\text { porewater } \\
\qquad 3_{\mathrm{s}}\end{array}$ & $\mathrm{S} 33_{\mathrm{d}}$ & $\mathrm{S} 4_{\mathrm{s}}$ & $\mathrm{S} 4_{\mathrm{d}}$ \\
\hline Porewater salinity & 0.3 & 0.2 & 3.1 & 1.8 & 17.0 & 17.7 & 28.0 & 32.1 \\
\hline $\mathrm{NO}_{3}(\mu \mathrm{M})$ & 36 & 37 & 17 & 26 & 66 & 17 & 78 & 7 \\
\hline $\mathrm{NO}_{2}^{-}(\mu \mathrm{M})$ & 0.2 & 0.4 & 0.1 & 0.3 & 0.9 & $<\mathrm{DL}$ & 1.0 & $<\mathrm{DL}$ \\
\hline $\mathrm{NH}_{4}^{+}(\mu \mathrm{M})$ & 12 & 67 & 12 & 25 & 73 & 934 & 166 & 126 \\
\hline $\mathrm{SO}_{4}^{2-}(\mathrm{mM})$ & 2 & 2 & 6 & 3 & 33 & 33 & 32 & 40 \\
\hline $\mathrm{Cl}^{-}(\mathrm{mM})$ & 4 & 3 & 49 & 28 & 265 & 276 & 347 & 501 \\
\hline Fe (aq) $(\mu \mathrm{M})$ & 0.4 & 4.9 & 0.1 & 0.3 & 1.6 & 3.6 & 0.9 & 3.3 \\
\hline \multirow[t]{3}{*}{$\mathrm{Mn}^{2+}(\mathrm{aq})(\mu \mathrm{M})$} & 3.4 & 82.3 & 5.1 & 49 & 60 & 0 & 15 & 62 \\
\hline & \multicolumn{8}{|c|}{ - Sediment - } \\
\hline & $\mathrm{S} 1_{\mathrm{s}}$ & $\mathrm{S} 1_{\mathrm{d}}$ & $\mathrm{S} 2_{\mathrm{s}}$ & $\mathrm{S} 2_{\mathrm{d}}$ & $\mathrm{S} 3_{\mathrm{s}}$ & $\mathrm{S} 3_{\mathrm{d}}$ & $\mathrm{S} 4_{\mathrm{s}}$ & $\mathrm{S} 4_{\mathrm{d}}$ \\
\hline Acid-extractable Fe $\left(\mu \mathrm{mol} \mathrm{g}{ }^{-1}\right)$ & $106 \pm 1$ & $116 \pm 10$ & $106 \pm 6$ & $105 \pm 4$ & $123 \pm 3$ & $206 \pm 8$ & $93 \pm 9$ & $191 \pm 28$ \\
\hline Acid-extractable $\mathrm{Fe}^{2+}(\mathrm{s})(\%)$ & 52 & 61 & 53 & 53 & 39 & 84 & 57 & 96 \\
\hline Total Fe (wt\%) & 2.1 & 2.7 & 2.7 & 2.4 & 3.5 & 4.0 & 4.3 & 3.9 \\
\hline$\%$ Fe-Pyrite & 0.08 & 0.10 & 0.09 & 0.10 & 0.10 & 0.12 & 0.12 & 0.18 \\
\hline$\% \mathrm{Fe}-\mathrm{AVS}$ & nd & nd & nd & nd & $<\mathrm{DL}$ & 0.01 & $<\mathrm{DL}$ & 0.09 \\
\hline$\%$ TOC & 1.3 & 2.3 & 2.5 & 1.8 & 2.1 & 2.6 & 2.2 & 2.7 \\
\hline$\% \mathrm{TS}$ & 0.16 & 0.18 & 0.18 & 0.14 & 0.22 & 0.35 & 0.31 & 0.52 \\
\hline Grain size $(\mu m)\left(D_{50}\right)$ & 57 & 51 & 52 & 49 & 14 & 17 & 14 & 17 \\
\hline$\%$ Water content & 42 & 39 & 41 & 28 & 65 & 44 & 64 & 40 \\
\hline
\end{tabular}


those in the water column, whereas ammonium concentrations were higher, especially in the sites where more reducing sediments were found. Sulfate concentrations increased with salinity from 1 to $22 \mathrm{mM}$ in the water column, and from 2 to $40 \mathrm{mM}$ in the porewater (there was no trend with sediment depth). The total amount of iron in solids did not vary with sediment depth but increased along the estuary. The proportion of the acidextractable Fe(II) was constant in the surface sediment; however, in the subsurface sediments, it increased along the estuary. Sediments of the mid- and outer estuary mudflats were also finer and contained slightly more TOC than sediments from the inner estuary sites.

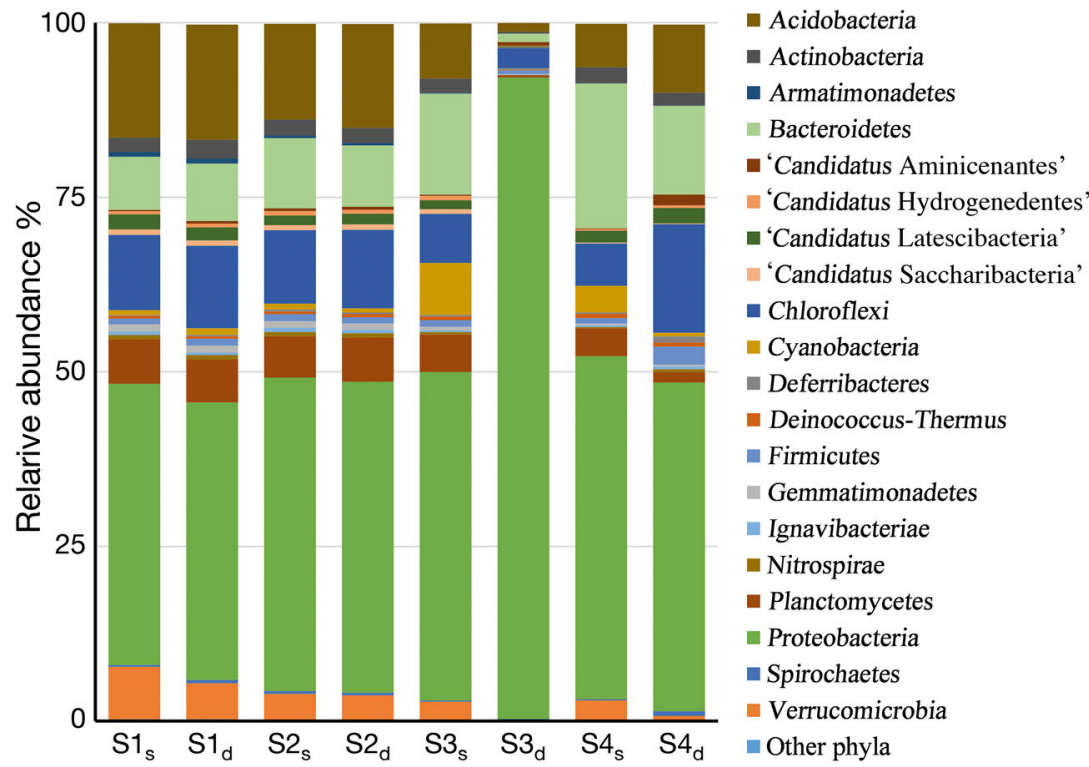

Fig. 3. Taxonomical composition of the bacterial community at the phylum level. Phyla with relative abundance below $0.1 \%$ are grouped as 'Other phyla'. Sampling sites (see Fig. 2) were S1: Boothferry, S2: Blacktoft, S3: Paull and S4: Skeffling; 's' and 'd' refer to surface and subsurface sediments, respectively

\section{Bacterial community composition and diversity along the salinity gradient}

The Illumina MiSeq run yielded >500000 pairedend reads per sample after quality control (Table S6 in Supplement 3). This dataset was randomly sampled to give exactly 500000 reads per sample. The combined pool of 4 million reads was used to identify the characteristic OTUs in the regional dataset. A total of 3596003 reads in the combined pool passed the chimera check, and these were clustered into OTUs (>97\% sequence identity), and assigned to taxonomic groups. The entire dataset of 6179119 reads was then allocated to these OTUs. The OTUs classified as Archaea (4\% of non-chimeric reads) and OTUs which were not classified to the bacterial phylum level with a confidence $>0.7$ (14\% of nonchimeric reads) were excluded from further analyses. This resulted in 5064424 reads that were allocated to 7656 OTUs.

Twenty phyla individually represented more than $0.1 \%$ on average of the total reads (Fig. 3), the most abundant of which were Proteobacteria (51\% on average of the total reads), Acidobacteria (11\%), Bacteroidetes (10\%) and Chloroflexi (9\%). At this taxonomic level, the community structure of all samples had a similar composition, with the exception of the sample of subsurface sediment from Paull $\left(\mathrm{S} 3_{\mathrm{d}}\right)$. In this sample, Proteobacteria were dominant, accounting for $92 \%$ of the OTUs present versus the
$45 \%$ (on average) that Proteobacteria represented at the other sites. Further information about the classification of each bacterial community to the class and order level can be found in Supplement 2 (Tables S1-S4).

A more detailed analysis of the phylum Proteobacteria reveals changes in composition along the estuary. The class Gammaproteobacteria was the most numerous and increased from $18 \%$ of total reads in the inner estuary to $25 \%$ of total reads in the outer estuary (sample $\mathrm{S} 3_{\mathrm{d}}$ is thought to be atypical, so, unless explicitly stated, it was omitted from the reported averages). This increase in abundance along the estuary was associated with an increase in the number of reads currently with uncertain placement (order incertae sedis; Table S2). Betaproteobacteria was the next most numerous class in the inner estuary samples, with $9 \%$ of total reads, but had $<3 \%$ of total reads in the outer estuary. On the other hand, it was notable that the abundance of Deltaproteobacteria was similar in all inner estuary samples and in the outer estuary surface samples $(\sim 7 \%$ of total reads), but represented $\sim 17 \%$ of $\mathrm{S} 4_{\mathrm{d}}$. This was mainly the result of an increase in the order Desulfobacterales from $\sim 2 \%$ of total reads in the inner estuary to $\sim 13 \%$ of total reads in $\mathrm{S} 4_{\mathrm{d}}$.

Acidobacteria was the second most abundant bacterial phylum, representing $\sim 15 \%$ of the total reads 
in the inner estuary, but only $\sim 8 \%$ of reads in the outer estuary samples. Within the Acidobacteria, subdivision 6 (class Acidobacteriia) was most numerous in the inner estuary ( $6 \%$ of total reads) but was only $1 \%$ of total reads in the outer estuary. Bacteroidetes was the third most abundant bacterial phylum, representing $\sim 9 \%$ of total reads in the inner estuary, but $\sim 16 \%$ of total reads in the outer estuary. Within the Bacteroidetes, the class Flavobacteriia was the most abundant in all the samples. Flavobacteriaceae was the dominant family in this class. Chloroflexi was the fourth most abundant bacterial phylum, and it exhibited very little systematic change along the estuary. The 2 most abundant classes within the Chloroflexi were Caldilineae and Anaerolineae ( 3 and $2 \%$, respectively, of total reads from the whole estuary).

The OTU richness, $D_{0}{ }^{\alpha}$, in each sample is shown in Fig. 4a. The average richness at the different sites and sediment depths was $~ 5000$ OTUs, although sites towards the outer estuary showed slightly lower $D_{0}{ }^{\alpha}$. Diversity measures that indicate the number of common OTUs $\left(D_{1}^{\alpha}\right)$ and dominant OTUs $\left(D_{2}^{\alpha}\right)$ both showed a stronger pattern of decreasing OTU diversity along the salinity gradient (Fig. 4b,c). These differences in OTU relative abundance between the inner and the outer zones of the estuary were significant (PERMANOVA analysis indicated $p<0.05$, F.Model was $>3.3$ if grouping by zone, and 2.2 if grouping by sampling location; see details in Supplement 8). Between the innermost and outermost estuary samples (S1 and S4) there was a drop in both $D_{1}{ }^{\alpha}$ and $D_{2}{ }^{\alpha}$ for the surface and the subsurface sediments by $60-70 \%$. To further illustrate the diversity trends, the values of $D_{1}{ }^{\alpha}$ and $D_{2}{ }^{\alpha}$ were used to estimate the percentage of reads within the common and dominant OTUs. Common OTUs accounted for $>80 \%$ of total sequence reads in all samples, and dominant
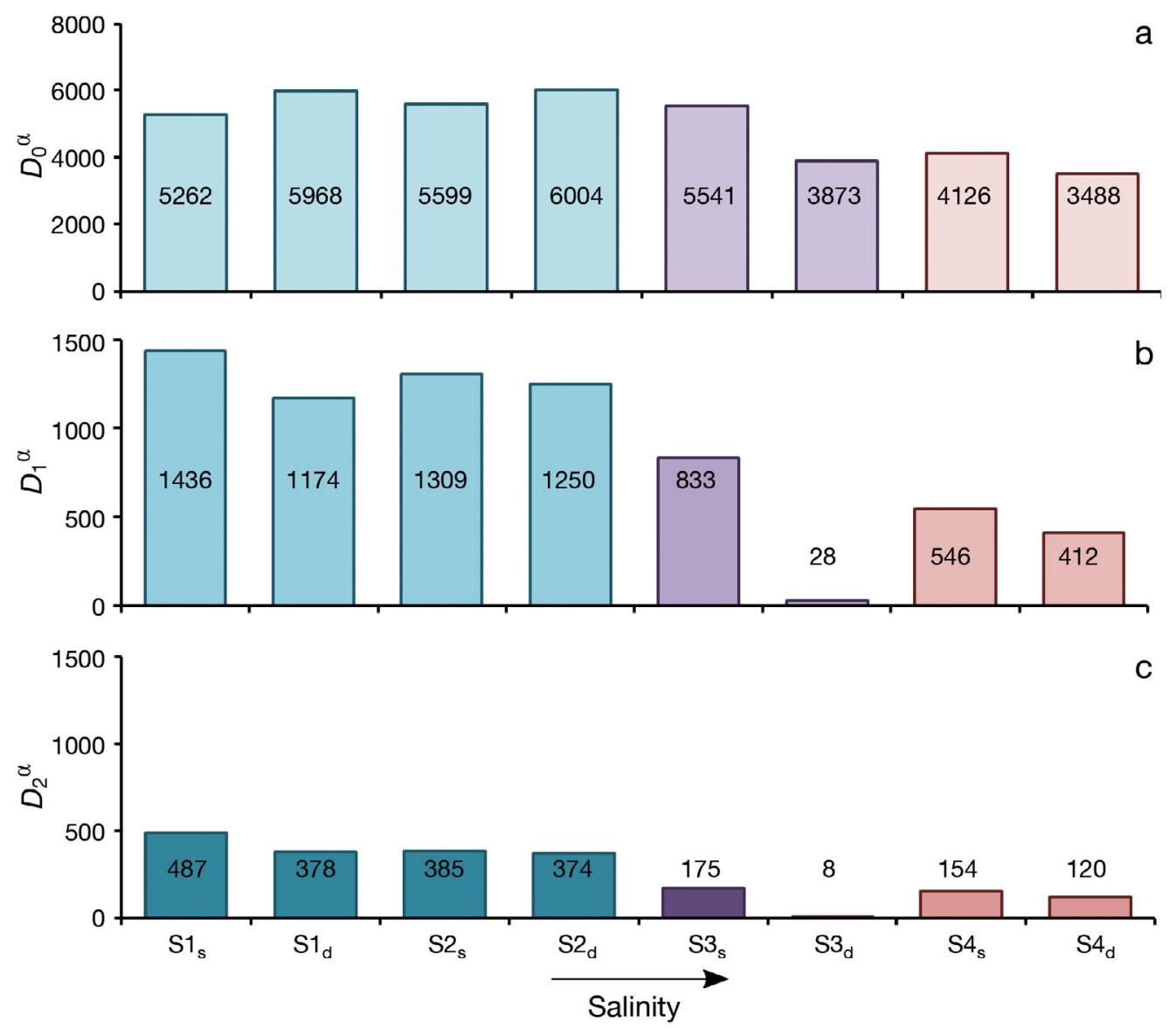

Fig. 4. Alpha-diversity $\left(D_{q}^{\alpha}\right)$ at each location measured with Hill numbers $\left(D_{q}\right)$ of different order $(q=0,1$ and 2$)$ which represent: (a) operational taxonomic unit (OTU) richness $\left(D_{0}{ }^{\alpha}\right)$, (b) common OTUs $\left(D_{1}^{\alpha}\right)$ and (c) dominant OTUs $\left(D_{2}{ }^{\alpha}\right)$. The colours of the bars follow the colour code for the inner (blue), mid- (purple) and outer (pink) estuary defined by salinity variation range (colour darkens as $q$ increases from $D_{0}{ }^{\alpha}$ to $D_{2}{ }^{\alpha}$ ). Sampling sites (see Fig. 2) were S1: Boothferry, S2: Blacktoft, S3: Paull and S4: Skeffling; 's' and 'd' refer to surface and subsurface sediments, respectively. For more details, see the 'Materials and methods' 
OTUs accounted for $54-73 \%$ of total sequence reads in all samples. Therefore, the decrease observed in the number of common and dominant OTUs along the estuary represented a shift towards fewer but more abundant OTUs towards the sea. The statistically weighted alpha-diversity $\left({ }^{*} D_{1}{ }^{\alpha}\right)$ was 438 OTUs; the regional diversity $\left(D_{1}^{\gamma}\right)$ was 934 OTUs, which, following Whittaker's multiplicative law, $\left(D_{1}{ }^{\beta}=D_{1}^{\gamma} /\right.$ $\left.{ }^{*} D_{1}^{\alpha}\right)$, gave a beta component $\left(D_{1}^{\beta}\right)$ of 2 .

NMDS analysis indicated that the variation of species frequencies in the samples is well represented in 2 dimensions (Fig. 5, stress value < 0.05). The NMDS ordination showed the split between the inner estuary samples, which were ordinated in a relatively close group, and the outer estuary samples that were progressively more distant from the inner estuary group. The mid- and outer estuary samples were also separated by depth, but there were too few samples to determine whether this difference was significant ( $p>0.05$, F.Model =0.84, see Supplement 8).

The BIOENV analysis showed that salinity, ammonium concentration in porewater and acid-extractable Fe(II) in solids were the subset of environmental variables that best correlated (0.94) with the community composition of the different sites along the Humber estuary (Mantel statistic based on Pearson correlation, $\mathrm{R}=0.72, \mathrm{p}<0.05$ ) (see Supplement 7).

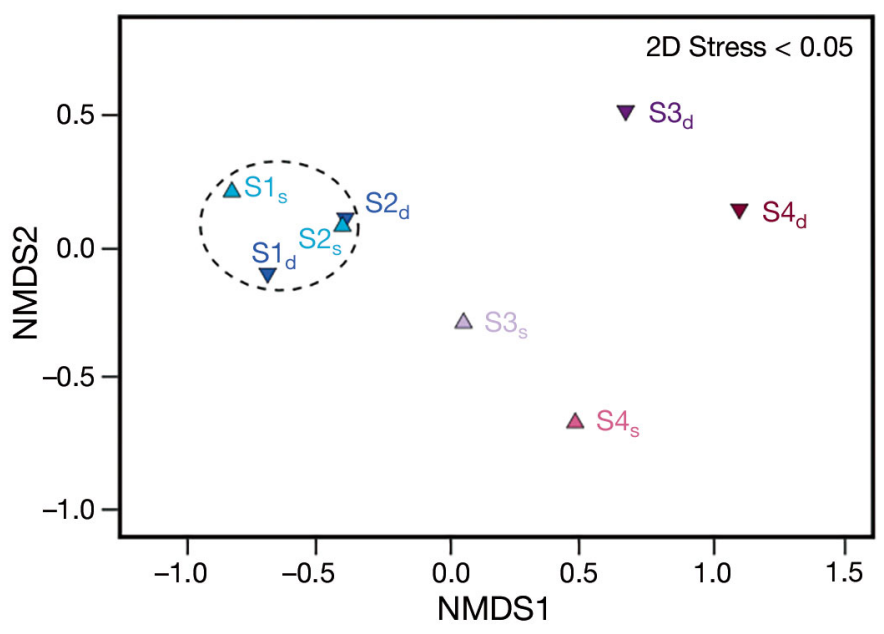

Fig. 5. Non-metric multidimensional scaling (NMDS) ordination for dissimilarities in the bacterial community distribution among samples based on Bray-Curtis distances. Samples are colour-coded according to the salinity variation zones (blue: inner, purple: mid-, pink: outer estuary). Lighter (darker) colours represent surface (subsurface) sediment samples. The dashed ellipse has been added to indicate the inner estuary samples. Sampling sites (see Fig. 2) were S1: Boothferry, S2: Blacktoft, S3: Paull and S4: Skeffling; 's' and 'd' refer to surface and subsurface sediments, respectively

\section{DISCUSSION}

\section{Environmental variability along the Humber estuary}

The Humber estuary is a shallow well-mixed estuary where water mixing is strongly driven by tidal forcing. Surface and subsurface sediments in the Humber are both subjected to reoxidation processes due to resuspension, albeit at strongly different frequencies of once per tidal cycle and once or twice a year, respectively (Mortimer et al. 1999a,b). Additionally, the spatial heterogeneity of nutrient concentrations and the patterns of movement of the estuarine turbidity maxima (ETM) within the Humber are influenced by seasonal variations of river flow (Sanders et al. 1997, Mitchell et al. 1999, Uncles et al. 1999). Intertidal fine-grained sediments support highly diverse microbial communities (Zinger et al. 2011, Reed \& Martiny 2013) and environmental gradients are likely to be shaping the spatial distribution of these communities in the estuarine systems (Findlay et al. 1990, Campbell \& Kirchman 2013, O'Sullivan et al. 2013, Liu et al. 2014, W. Zhang et al. 2014, Wei et al. 2016).

The large-scale spatial gradients in salinity and nutrient concentrations observed in this study are reflective of natural environmental gradients expected within estuarine systems (Crump et al. 2004, Liu et al. 2014, Jeffries et al. 2016). Overall, the midestuary river waters experience the widest salinity variation in the Humber. However, porewater salinity is expected to change more slowly than estuarine water salinity in muddy, fine-grained sediments due to their lower permeability (Harrison \& Phizacklea 1987, Musat et al. 2006), and, therefore, it probably varies less and remains close to the long-term average salinity of the overlying waters. Concentrations of nitrate decreased in the water column towards the outer estuary, while sulfate increased with increasing proportions of seawater mixed in the water column. The main difference between the inner and the mid-/ outer estuarine sediments was the more reducing nature of the latter. The sediments recovered from the mudflats of the mid- and outer estuary showed some iron enrichment compared to the sites from the inner estuary. Iron and ammonium concentrations in the porewater also increased toward the marine end of the system, as did the proportion of acid-extractable Fe(II) found in subsurface sediments. Field observations of the sediment colour at the mid- and outer estuary sites (reddish-brown at the surface but dark grey-black in the subsurface) evidenced an 
abrupt redoxcline at these sites. Although $\mathrm{H}_{2} \mathrm{~S}$ concentrations were not measured and AVS concentrations were relatively low, others have reported that the subsurface sediments of the outer estuary Humber mudflats can be sulfidic (Mortimer et al. 1999a, Andrews et al. 2000). Such an abrupt redox change with depth was probably not developed at the inner estuary sites, where the subsurface sediments appeared to be poised between nitrate and iron-reducing conditions. Sediment was finer in the samples from the mid- and outer estuary, which may have further implications in the temperature gradients, organic matter turnover and the erodibility of the sediments (Harrison \& Phizacklea 1987, Blanchard et al. 2000, Bühring et al. 2005, Musat et al. 2006).

\section{Bacterial community composition along the salinity gradient}

Taxonomically, all samples except for $\mathrm{S}_{\mathrm{d}}$ had a similar composition. Proteobacteria was the most represented phylum in all bacterial communities, followed by Acidobacteria, Bacteroidetes and Chloroflexi. This distribution of phyla was consistent with other studies in coastal and estuarine sediments (Wang et al. 2012, Halliday et al. 2014, Liu et al. 2014, Jeffries et al. 2016, Wei et al. 2016, Pavloudi et al. 2017). The increase in abundance of Proteobacteria along the estuary was mainly the result of an increase in abundance of Gammaproteobacteria incertae sedis. The detailed phylogenetic relationships in this taxonomic group are currently unknown, but it contains many aerobic and facultative anaerobic genera recovered from brackish and saline environments (Distel et al. 2002, Romanenko et al. 2004, Lin \& Shieh 2006, Spring et al. 2009), so this increased abundance may be related to increasing salinity (Pavloudi et al. 2017). Furthermore, the increase in abundance of reads from the order Desulfobacterales in sample $\mathrm{S} 4_{\mathrm{d}}$ could be a response to the salinity and redox conditions in the outer estuary subsurface sediments, as this order contains strictly anaerobic sulfate-reducing bacteria that are most frequently found in tidal mudflats and marine habitats (Mußmann et al. 2005, Wilms et al. 2006, Gittel et al. 2008, Kuever 2014, Pavloudi et al. 2017). There was also an increase in the abundance of Bacteroidetes along the estuary, and particularly of species in the family Flavobacteriaceae. The marine genera of Flavobacteriaceae are a major component of the oceanic microbial biomass in the pelagic zone (Kirchman 2002, McBride 2014) and have also been found in tidal sediments (Jung et al. 2005, Choi \& Cho 2006, Wilms et al. 2006). Acidobacteria are ubiquitous and abundant in nature, and especially in soils (Barns et al. 1999, Rappé \& Giovannoni 2003). A decrease in the abundance of Acidobacteria along the estuary (as a result of a decrease in the abundance of subdivision 6) was observed, which may be related to soil inputs at the inner estuary. Members of subdivision 6 (Class Acidobacteriia) are widespread in terrestrial and marine environments, and tend to be highly abundant in nutrient-rich environments (Janssen 2006, Kielak et al. 2016).

The taxonomic composition of sample $\mathrm{S} 3_{\mathrm{d}}$ differed markedly from the other samples. Here, the bacterial community was dominated by Epsilonproteobacteria. This taxonomic group has been found in other estuarine and coastal sediments and pelagic redoxclines (Labrenz et al. 2005, Campbell et al. 2006, Grote et al. 2008, Bruckner et al. 2013, Jeffries et al. 2016), and is occasionally abundant (Wang et al. 2012). Epsilonproteobacteria have been suggested to be among the dominant microorganisms involved in the coupling of $\mathrm{C}, \mathrm{N}$ and $\mathrm{S}$ cycles (Campbell et al. 2006). Many Epsilonproteobacteria within the order of Campylobacterales (the most important in sample $\mathrm{S} 3_{\mathrm{d}}$ ) are microaerophilic chemolithotrophs that can couple the oxidation of sulfur compounds or hydrogen to the reduction of manganese, oxygen or nitrate (Thamdrup et al. 2000, Labrenz et al. 2005, Campbell et al. 2006, Grote et al. 2008, Bruckner et al. 2013). This taxonomic group has also been associated with shellfish (as a reservoir of food-borne and waterborne pathogens) and faecal pollution (Levican et al. 2014). The low bacterial diversity measured in sample $\mathrm{S} 3_{\mathrm{d}}$ was unexpected and could be due to the sampling of a specialist niche (the dominance of Campylobacterales may be related to the reducing geochemical conditions at this location) (Teske et al. 1996, Llobet-Brossa et al. 1998, Thamdrup et al. 2000). However, other causes of these anomalous results (i.e. sampling or sequencing technology biases, or the proximity of shellfish to the sample) cannot be discarded.

\section{Trends and environmental drivers of microbial diversity}

Ever since the publication of Remane's model, there has been substantial interest in the role of salinity stress in shaping estuarine biodiversity (Attrill 2002, Whitfield et al. 2012). In this study, we found that the OTU richness of benthic bacteria (as meas- 
ured by $D_{0}{ }^{\alpha}$ ) was relatively uniform along the Humber estuary, which appears to agree with previous reports of uniform bacterial richness along a salinity gradient (Hewson et al. 2007, Herlemann et al. 2011, W. Zhang et al. 2014). In contrast, Pavloudi et al. (2017) found that the total number of OTUs showed a negative relationship with increasing salinity. However, due to the hyperdiverse nature of microorganisms in many ecosystems, richness can give a distorted view of microbial diversity because it gives equal weight to common and rare taxa (i.e. richness takes no account of OTU relative abundance). Also, it is seldom possible to evaluate richness accurately, as it is extremely difficult to adequately sample rare taxa even with high-throughput sequencing technologies (Kang et al. 2016). Therefore Hill numbers of higher order ( $q=1$ or 2 ) are considered to be a more suitable mathematical approach to microbial diversity that give consistent measures of the prominence of common or dominant species in a community since they are not sensitive to sequencing depth (Kang et al. 2016).

The analysis of the microbial diversity in the Humber mudflats using $D_{1}{ }^{\alpha}$ and $D_{2}{ }^{\alpha}$ revealed a decreasing trend of microbial diversity in terms of common and dominant OTUs with increasing salinity. The common and dominant OTUs in the mid- and outer estuary samples were only about 40 and $35 \%$ of the average number of common and dominant OTUs, respectively, in the inner estuary. This indicated a change towards a community structure with a smaller number of more abundant OTUs along the estuarine salinity gradient. Other studies also reported a similar decreasing trend in pelagic and benthic bacterial diversity along the salinity gradient (Campbell \& Kirchman 2013, Liu et al. 2014, L. Zhang et al. 2014, Wang et al. 2015), which may be in part be explained by the influence of the riverine inputs on the inner estuary communities (Crump et al. 1999, Rappé et al. 2000, L. Zhang et al. 2014, Monard et al. 2016). Generally, Site 3 fitted this trend, despite being in the area of highest salinity variation. The surface sample $\left(\mathrm{S} 3_{\mathrm{s}}\right)$ showed $D_{1}{ }^{\alpha}$ and $D_{2}{ }^{\alpha}$ measurements that were intermediate between the inner and outer estuary, which was not surprising given the regular resuspension and mixing processes of surface sediments by tidal forces. However, as mentioned above, the subsurface sample $\left(\mathrm{S} 3_{\mathrm{d}}\right)$ showed lower $D_{1}{ }^{\alpha}$ and $D_{2}{ }^{\alpha}$ values than any other sample analysed. This could be associated with salinity stress, or possibly sampling or sequencing bias, but it is more likely that some other environmental pressure had produced a specialist niche that favoured just a few bacterial species at this location. DNA was extracted from $<0.5 \mathrm{~g}$ of sediment, and thus very local geochemical effects could affect the bacterial community within individual samples.

NMDS ordination showed differences in the bacterial community associated with progression toward the outer estuary. Also, all of the inner estuary samples were clustered together in this analysis, suggesting that the bacterial populations of the inner estuary mudflats were not significantly different between depths. The colour pattern in the heat map (see Fig. S3 in Supplement 6) also showed these samples as being similar in their composition. The effects of the mixing at the ETM and the presence of more coarse sediments could enhance the homogenisation of surface and subsurface bacterial communities (Crump et al. 1999, Bühring et al. 2005, Musat et al. 2006, Feng et al. 2009, Lavergne et al. 2017). The NMDS analysis also separated the subsurface midand outer estuary samples from their surface counterparts, but insufficient samples were used to determine whether this trend was significant. Nevertheless, field observations and geochemical measurements indicated that subsurface mid- and outer estuarine sediments were more reducing than the inner estuarine sediments. Other studies in similar environmental conditions suggested that such vertical stratification in the microbial communities should be expected in the presence of strong redox stratification in estuarine mudflats (Musat et al. 2006, Bertics \& Ziebis 2009, O'Sullivan et al. 2013, Liu et al. 2014, Lavergne et al. 2017).

Overall, salinity, ammonium concentration in porewater and acid-extractable Fe(II) in solids were the set of environmental variables that best explained the variability of our dataset. Although the significance of salinity determining microbial compositions has been well documented, the importance of other environmental variables may be hidden as they covary with salinity along the gradient. For example, Liu et al. (2014) found that sulfate concentration might be hidden by salinity as a driver for the distinct distribution of methanogens and sulfate-reducing bacteria between fresh- and seawater sediments. Stronger redox stratification would be expected in the less frequently disturbed subsurface sediments, which in the more sulfidic mid- and outer Humber mudflats may provide the geochemical conditions for more specialist communities to develop (Hewson \& Fuhrman 2004, Bertics \& Ziebis 2009). We suggest that the weaker redox stratification in the inner Humber estuary is likely the reason for the similarity of the microbial populations between depths, al- 
though the coarser (i.e. more permeable) nature of the inner mudflats and the position of the ETM (i.e. more intense mixing) could also be enhancing the uniformity of the microbial populations in the freshwater end of the Humber as mentioned before. Apart from the resuspension, other external parameters (temperature, wind, tidal cycle, light exposure, organic matter, benthic fauna and microphytobenthic activity) probably influence the distribution of bacterial communities, especially in the surface sediment layer. These could cause important seasonal differences in microbial metabolism in different zones, as observed by different authors (Hubas et al. 2007, Orvain et al. 2014, Lavergne et al. 2017).

The regional microbial diversity of the Humber estuary $\left(D_{1}^{\gamma}=934\right.$ OTUs) indicated that many of the OTUs that were common in individual samples were common within the regional dataset. Further, the beta diversity, calculated for common species $\left(D_{1}{ }^{\beta} \sim 2\right)$ can be interpreted as there being 2 distinct assemblages dispersed amongst the various local communities of the region. We suggest that the first of these compositional units may be a community that is subjected to resuspension into the water column and laterally transported along the estuary. Hence, this community may be stressed by the varying salinity conditions (there will be less of a direct link between the geochemistry and the bacterial community in frequently disturbed estuarine sediments) (O'Sullivan et al. 2013). The second compositional unit may develop in the more strongly reducing and less frequently disturbed subsurface sediments of the mid- and outer estuary mudflats, which is in agreement with the multivariate analysis results.

\section{Conclusions}

This study has provided initial insight into the microbial diversity of the Humber estuary. Although no biological replicates were used, the large amount of data produced by using high throughput sequencing technologies resulted in a deep coverage of the individual samples. A taxonomic approach to the community data did not show clear differences between sampling sites. Similarly, OTU richness, $D_{0}{ }^{\alpha}$, was relatively uniform for benthic bacteria in the estuary, which challenges the Remane concept. However, Hill numbers of higher order $\left(D_{1}{ }^{\alpha}\right.$ and $\left.D_{2}{ }^{\alpha}\right)$ decreased towards the sea, which indicates a change towards communities where a smaller number of OTUs represents a larger proportion of the popula- tion. The discovery of this trend along the salinity gradient illustrated the importance of using a rigorous and consistent mathematical approach to characterise bacterial diversity, particularly when working with amplicon sequencing data. Beyond salinity variation, there was some evidence that redox transitions with depth may apply further selective pressure on the microbial populations of the mid- and outer mudflats, but other spatiotemporal fluctuations in the physico-chemical conditions (sediment resuspension and mixing) may also have an impact on the bacterial community composition. Future investigations with a wider sampling strategy and more biological replicates would be needed to confirm these findings, as well as to explore more deeply the effects of these and other biotic and abiotic variables on microbial diversity through different seasons.

Acknowledgements. We especially thank the Centre for Genomic Research, University of Liverpool, for their support before and after the sequencing and Robert C. Edgar for his help and thorough advice in the use of USEARCH for bioinformatics. Many thanks to R. Rigby for his help with Linux OS, and to S. Lutz for her bioinformatics tips. We are grateful to S. Reid, A. Stockdale (ORCID ID: 0000-0002-1603-0103), A. Connelly, F. Keay, D. Ashley, G. Keevil, R. Thomas, S. Poulton (ORCID ID: 0000-0001-7621-189X) and J. Thompson (all from University of Leeds) for technical support in the geochemical analyses. A.V.D. was funded by a University of Leeds Doctoral Training Award. We acknowledge support from the NERC Bioinformatics Centre, Liverpool, under grant NE/L01405X/1.

\section{LITERATURE CITED}

Anderson MJ (2001) A new method for non-parametric multivariate analysis of variance. Austral Ecol 26:32-46

Andrews JE, Samways G, Dennis PF, Maher BA (2000) Origin, abundance and storage of organic carbon and sulphur in the Holocene Humber Estuary: emphasizing human impact on storage changes. Geol Soc Lond Spec Publ 166:145-170

Attrill MJ (2002) A testable linear model for diversity trends in estuaries. J Anim Ecol 71:262-269

Attrill MJ, Rundle SD (2002) Ecotone or ecocline: ecological boundaries in estuaries. Estuar Coast Shelf Sci 55:929-936

* Barnes RSK (1989) What, if anything, is a brackish water fauna? Trans R Soc Edinb Earth Sci 80:235-240

* Barns SM, Takala SL, Kuske CR (1999) Wide distribution and diversity of members of the bacterial kingdom Acidobacterium in the environment. Appl Environ Microbiol 65:1731-1737

Bertics VJ, Ziebis W (2009) Biodiversity of benthic microbial communities in bioturbated coastal sediments is controlled by geochemical microniches. ISME J 3:1269-1285

Bier RL, Bernhardt ES, Boot CM, Graham EB and others (2015) Linking microbial community structure and microbial processes: an empirical and conceptual overview. FEMS Microbiol Ecol 91 
Blanchard GF, Paterson DM, Stal LJ, Richard P and others (2000) The effect of geomorphological structures on potential biostabilisation by microphytobenthos on intertidal mudflats. Cont Shelf Res 20:1243-1256

Bruckner CG, Mammitzsch K, Jost G, Wendt J, Labrenz M, Juergens K (2013) Chemolithoautotrophic denitrification of epsilonproteobacteria in marine pelagic redox gradients. Environ Microbiol 15:1505-1513

Bühring SI, Elvert M, Witte U (2005) The microbial community structure of different permeable sandy sediments characterized by the investigation of bacterial fatty acids and fluorescence in situ hybridization. Environ Microbiol 7:281-293

* Bulger AJ, Hayden BP, Monaco ME, Nelson DM, McCormickray MG (1993) Biologically-based estuarine salinity zones derived from a multivariate-analysis. Estuaries 16:311-322

Buttigieg PL, Ramette A (2014) A guide to statistical analysis in microbial ecology: a community-focused, living review of multivariate data analyses. FEMS Microbiol Ecol 90:543-550

* Campbell BJ, Kirchman DL (2013) Bacterial diversity, community structure and potential growth rates along an estuarine salinity gradient. ISME J 7:210-220

Campbell BJ, Engel AS, Porter ML, Takai K (2006) The versatile $\varepsilon$-proteobacteria: key players in sulphidic habitats. Nat Rev Microbiol 4:458-468

* Canfield DE, Thamdrup B (2009) Towards a consistent classification scheme for geochemical environments, or, why we wish the term 'suboxic' would go away. Geobiology 7:385-392

* Canfield DE, Raiswell R, Westrich JT, Reaves CM, Berner RA (1986) The use of chromium reduction in the analysis of reduced inorganic sulfur in sediments and shales. Chem Geol 54:149-155

Caporaso JG, Lauber CL, Walters WA, Berg-Lyons D and others (2011) Global patterns of 16S rRNA diversity at a depth of millions of sequences per sample. Proc Natl Acad Sci USA 108(Suppl 1):4516-4522

* Chao A, Gotelli NJ, Hsieh TC, Sander EL, Ma KH, Colwell RK, Ellison AM (2014) Rarefaction and extrapolation with Hill numbers: a framework for sampling and estimation in species diversity studies. Ecol Monogr 84:45-67

Choi DH, Cho BC (2006) Lutibacter litoralis gen. nov., sp. nov., a marine bacterium of the family Flavobacteriaceae isolated from tidal flat sediment. Int J Syst Evol Microbiol 56:771-776

Clarke KR, Ainsworth M (1993) A method of linking multivariate community structure to environmental variables. Mar Ecol Prog Ser 92:205-219

* Crump BC, Armbrust EV, Baross JA (1999) Phylogenetic analysis of particle-attached and free-living bacterial communities in the Columbia river, its estuary, and the adjacent coastal ocean. Appl Environ Microbiol 65:3192-3204

* Crump BC, Hopkinson CS, Sogin ML, Hobbie JE (2004) Microbial biogeography along an estuarine salinity gradient: combined influences of bacterial growth and residence time. Appl Environ Microbiol 70:1494-1505

* Distel DL, Morrill W, MacLaren-Toussaint N, Franks D, Waterbury J (2002) Teredinibacter turnerae gen. nov., sp nov., a dinitrogen-fixing, cellulolytic, endosymbiotic $\gamma$-proteobacterium isolated from the gills of wood-boring molluscs (Bivalvia: Teredinidae). Int J Syst Evol Microbiol 52:2261-2269
Edgar RC (2010) Search and clustering orders of magnitude faster than BLAST. Bioinformatics 26:2460-2461

Edgar RC (2013) UPARSE: highly accurate OTU sequences from microbial amplicon reads. Nat Methods 10: 996-998

Elliott M, Whitfield AK (2011) Challenging paradigms in estuarine ecology and management. Estuar Coast Shelf Sci 94:306-314

FFederle TW, Hullar MA, Livingston RJ, Meeter DA, White DC (1983) Spatial distribution of biochemical parameters indicating biomass and community composition of microbial assemblies in estuarine mud flat sediments. Appl Environ Microbiol 45:58-63

Feng BW, Li XR, Wang JH, Hu ZY, Meng H, Xiang LY, Quan ZX (2009) Bacterial diversity of water and sediment in the Changjiang estuary and coastal area of the East China Sea. FEMS Microbiol Ecol 70:236-248

Findlay RH, Trexler MB, White DC (1990) Response of a benthic microbial community to biotic disturbance. Mar Ecol Prog Ser 62:135-148

Fossing H, Jørgensen BB (1989) Measurement of bacterial sulfate reduction in sediments - evaluation of a singlestep chromium reduction method. Biogeochemistry 8:205-222

*Gittel A, Mußmann M, Sass H, Cypionka H, Könneke M (2008) Identity and abundance of active sulfate reducing bacteria in deep tidal flat sediments determined by directed cultivation and CARD FISH analysis. Environ Microbiol 10:2645-2658

Frote J, Jost G, Labrenz M, Herndl GJ, Juergens K (2008) Epsilonproteobacteria represent the major portion of chemoautotrophic bacteria in sulfidic waters of pelagic redoxclines of the Baltic and Black Seas. Appl Environ Microbiol 74:7546-7551

*Halliday E, McLellan SL, Amaral-Zettler LA, Sogin ML, Gast RJ (2014) Comparison of bacterial communities in sands and water at beaches with bacterial water quality violations. PLOS ONE 9:e90815

* Harrison SJ, Phizacklea AP (1987) Temperature fluctuation in muddy intertidal sediments, Forth Estuary, Scotland. Estuar Coast Shelf Sci 24:279-288

* Herlemann DPR, Labrenz M, Jurgens K, Bertilsson S, Waniek JJ, Andersson AF (2011) Transitions in bacterial communities along the $2000 \mathrm{~km}$ salinity gradient of the Baltic Sea. ISME J 5:1571-1579

*Hewson I, Fuhrman JA (2004) Richness and diversity of bacterioplankton species along an estuarine gradient in Moreton Bay, Australia. Appl Environ Microbiol 70: 3425-3433

* Hewson I, Jacobson-Meyers ME, Fuhrman JA (2007) Diversity and biogeography of bacterial assemblages in surface sediments across the San Pedro Basin, Southern California Borderlands. Environ Microbiol 9:923-933

Hill MO (1973) Diversity and evenness: a unifying notation and its consequences. Ecology 54:427-432

*House WA, Leach D, Warwick MS, Whitton BA and others (1997) Nutrient transport in the Humber rivers. Sci Total Environ 194-195:303-320

*Hubas C, Lamy D, Artigas LF, Davoult D (2007) Seasonal variability of intertidal bacterial metabolism and growth efficiency in an exposed sandy beach during low tide. Mar Biol 151:41-52

Janssen PH (2006) Identifying the dominant soil bacterial taxa in libraries of 16S rRNA and 16S rRNA genes. Appl Environ Microbiol 72:1719-1728 
Jeffries TC, Schmitz Fontes ML, Harrison DP, Van-DongenVogels V, Eyre BD, Ralph PJ, Seymour JR (2016) Bacterioplankton dynamics within a large anthropogenically impacted urban estuary. Front Microbiol 6:1438

Jost L (2006) Entropy and diversity. Oikos 113:363-375

Jost L (2007) Partitioning diversity into independent alpha and beta components. Ecology 88:2427-2439

Jung SY, Kang SJ, Lee MH, Lee SY, Oh TK, Yoon JH (2005) Gaetbulibacter saemankumensis gen. nov., sp. nov., a novel member of the family Flavobacteriaceae isolated from a tidal flat sediment in Korea. Int J Syst Evol Microbiol 55:1845-1849

Kang S, Rodrigues JLM, Ng JP, Gentry TJ (2016) Hill number as a bacterial diversity measure framework with high-throughput sequence data. Sci Rep 6:38263

Khlebovich VV (1968) Some peculiar features of the hydrochemical regime and the fauna of mesohaline waters. Mar Biol 2:47-49

Kielak AM, Barreto CC, Kowalchuk GA, van Veen JA, Kuramae EE (2016) The ecology of Acidobacteria: moving beyond genes and genomes. Front Microbiol 7:744

Kirchman DL (2002) The ecology of Cytophaga-Flavobacteria in aquatic environments. FEMS Microbiol Ecol 39: 91-100

Klier J, Dellwig O, Leipe T, Jürgens K, Herlemann DP (2018) Benthic bacterial community composition in the oligohaline-marine transition of surface sediments in the Baltic Sea based on rRNA analysis. Front Microbiol 9:236

Kuever J (2014) The Family Desulfobacteraceae. In: Rosenberg E, DeLong EF, Lory S, Stackebrandt E, Thompson F (eds) The prokaryotes: Deltaproteobacteria and Epsilonproteobacteria. Springer, Berlin, p 45-73

Labrenz M, Jost G, Pohl C, Beckmann S, Martens-Habbena W, Jurgens K (2005) Impact of different in vitro electron donor/acceptor conditions on potential chemolithoautotrophic communities from marine pelagic redoxclines. Appl Environ Microbiol 71:6664-6672

Lallias D, Hiddink JG, Fonseca VG, Gaspar JM and others (2015) Environmental metabarcoding reveals heterogeneous drivers of microbial eukaryote diversity in contrasting estuarine ecosystems. ISME J 9:1208-1221

Kavergne C, Agogué H, Leynaert A, Raimonet M and others (2017) Factors influencing prokaryotes in an intertidal mudflat and the resulting depth gradients. Estuar Coast Shelf Sci 189(Suppl C):74-83

Kevican A, Collado L, Yustes C, Aguilar C, Figueras MJ (2014) Higher water temperature and incubation under aerobic and microaerobic conditions increase the recovery and diversity of Arcobacter spp. from shellfish. Appl Environ Microbiol 80:385-391

Lin YT, Shieh WY (2006) Zobellella denitrificans gen. nov., sp. nov. and Zobellella taiwanensis sp. nov., denitrifying bacteria capable of fermentative metabolism. Int J Syst Evol Microbiol 56:1209-1215

Liu J, Yang H, Zhao M, Zhang XH (2014) Spatial distribution patterns of benthic microbial communities along the Pearl Estuary, China. Syst Appl Microbiol 37:578-589

Llobet-Brossa E, Rossello-Mora R, Amann R (1998) Microbial community composition of Wadden Sea sediments as revealed by fluorescence in situ hybridization. Appl Environ Microbiol 64:2691-2696

Kovley DR, Phillips EJP (1987) Rapid assay for microbially reducible ferric iron in aquatic sediments. Appl Environ Microbiol 53:1536-1540
Lozupone CA, Knight R (2007) Global patterns in bacterial diversity. Proc Natl Acad Sci USA 104:11436-11440

Martin M (2011) Cutadapt removes adapter sequences from high-throughput sequencing reads. EMBnet J 17:10-12

McBride MJ (2014) The Family Flavobacteriaceae. In: Rosenberg E, DeLong EF, Lory S, Stackebrandt E, Thompson F (eds) The prokaryotes: other major lineages of Bacteria and the Archaea. Springer, Berlin, p 643-676

* Mitchell SB, West RJ, Arundale AMW, Guymer I, Couperthwaite JS (1999) Dynamics of the turbidity maxima in the Upper Humber Estuary System, UK. Mar Pollut Bull 37:190-205

*Monard C, Gantner S, Bertilsson S, Hallin S, Stenlid J (2016) Habitat generalists and specialists in microbial communities across a terrestrial-freshwater gradient. Sci Rep 6:37719

* Mortimer RJG, Krom MD, Watson PG, Frickers PE, Davey JT, Clifton RJ (1999a) Sediment-water exchange of nutrients in the intertidal zone of the Humber estuary, UK. Mar Pollut Bull 37:261-279

Mortimer RJG, Davey JT, Krom MD, Watson PG, Frickers PE, Clifton RJ (1999b) The effect of macrofauna on porewater profiles and nutrient fluxes in the intertidal zone of the Humber Estuary. Estuar Coast Shelf Sci 48:683-699

*Musat N, Werner U, Knittel K, Kolb S and others (2006) Microbial community structure of sandy intertidal sediments in the North Sea, Sylt-Rømø Basin, Wadden Sea. Syst Appl Microbiol 29:333-348

* Mußmann M, Ishii K, Rabus R, Amann R (2005) Diversity and vertical distribution of cultured and uncultured Deltaproteobacteria in an intertidal mud flat of the Wadden Sea. Environ Microbiol 7:405-418

\% O'Sullivan LA, Sass AM, Webster G, Fry JC, Parkes RJ, Weightman AJ (2013) Contrasting relationships between biogeochemistry and prokaryotic diversity depth profiles along an estuarine sediment gradient. FEMS Microbiol Ecol 85:143-157

Oksanen J, Blanchet FG, Kindt R, Legendre P and others (2013) vegan: Community Ecology Package. R package version 2.0-10. http://CRAN.R-project.org/package=vegan

* Orvain F, De Crignis M, Guizien K, Lefebvre S, Mallet C, Takahashi E, Dupuy C (2014) Tidal and seasonal effects on the short-term temporal patterns of bacteria, microphytobenthos and exopolymers in natural intertidal biofilms (Brouage, France). J Sea Res 92(Suppl C):6-18

Oulas A, Pavloudi C, Polymenakou P, Pavlopoulos GA and others (2015) Metagenomics: tools and insights for analyzing next-generation sequencing data derived from biodiversity studies. Bioinform Biol Insights 9:75-88

* Pavloudi C, Kristoffersen JB, Oulas A, De Troch M, Arvanitidis C (2017) Sediment microbial taxonomic and functional diversity in a natural salinity gradient challenge Remane's 'species minimum' concept. PeerJ 5:e3687

* Rappé MS, Giovannoni SJ (2003) The uncultured microbial majority. Annu Rev Microbiol 57:369-394

* Rappé MS, Vergin K, Giovannoni SJ (2000) Phylogenetic comparisons of a coastal bacterioplankton community with its counterparts in open ocean and freshwater systems. FEMS Microbiol Ecol 33:219-232

* Reed HE, Martiny JBH (2013) Microbial composition affects the functioning of estuarine sediments. ISME J 7 : 868-879

Remane A (1934) Die Brackwasserfauna. Zool Anz 7 (Suppl):34-74

* Romanenko LA, Schumann P, Rohde M, Mikhailov VV, 
Stackebrandt E (2004) Reinekea marinisedimentorum gen. nov., sp nov., a novel gammaproteobacterium from marine coastal sediments. Int $\mathrm{J}$ Syst Evol Microbiol 54:669-673

RStudio Team (2015) RStudio: integrated development environment for R (Version.0.99.486). RStudio, Boston, MA

Sanders RJ, Jickells T, Malcolm S, Brown J and others (1997) Nutrient fluxes through the Humber estuary. J Sea Res $37: 3-23$

Schubert H, Feuerpfeil P, Marquardt R, Telesh I, Skarlato S (2011) Macroalgal diversity along the Baltic Sea salinity gradient challenges Remane's species-minimum concept. Mar Pollut Bull 62:1948-1956

Skarlato S, Telesh I (2017) The development of the protistan species-maximum concept for the critical salinity zone. Russ J Mar Biol 43:1-11

Spring S, Luensdorf H, Fuchs BM, Tindall BJ (2009) The photosynthetic apparatus and its regulation in the aerobic Gammaproteobacterium Congregibacter litoralis gen. nov., sp nov. PLOS ONE 4:e4866

Telesh IV, Schubert H, Skarlato SO (2011) Revisiting Remane's concept: evidence for high plankton diversity and a protistan species maximum in the horohalinicum of the Baltic Sea. Mar Ecol Prog Ser 421:1-11

Telesh I, Schubert H, Skarlato S (2013) Life in the salinity gradient: discovering mechanisms behind a new biodiversity pattern. Estuar Coast Shelf Sci 135:317-327

Teske A, Sigalevich P, Cohen Y, Muyzer G (1996) Molecular identification of bacteria from a coculture by denaturing gradient gel electrophoresis of $16 \mathrm{~S}$ ribosomal DNA fragments as a tool for isolation in pure cultures. Appl Environ Microbiol 62:4210-4215

Thamdrup B, Rosselló-Mora R, Amann R (2000) Microbial manganese and sulfate reduction in Black Sea shelf sediments. Appl Environ Microbiol 66:2888-2897

Turner S, Pryer KM, Miao VP, Palmer JD (1999) Investigating deep phylogenetic relationships among cyanobacteria and plastids by small subunit rRNA sequence analysis. J Eukaryot Microbiol 46:327-338

Uncles RJ, Easton AE, Griffiths ML, Harris C and others

Editorial responsibility: Rutger de Wit, Montpellier, France
(1999) Seasonality of the turbidity maximum in the Humber-Ouse Estuary, UK. Mar Pollut Bull 37:206-215

*Viollier E, Inglett PW, Huntrer K, Roychoudhury AN, Van Cappellen P (2000) The ferrozine method revised: Fe(II)/ Fe(III) determination in natural waters. Appl Geochem 15:785-790

*Wang K, Ye X, Chen H, Zhao Q and others (2015) Bacterial biogeography in the coastal waters of northern Zhejiang, East China Sea is highly controlled by spatially structured environmental gradients. Environ Microbiol 17:3898-3913

* Wang Y, Sheng HF, He Y, Wu JY, Jiang YX, Tam NFY, Zhou HW (2012) Comparison of the levels of bacterial diversity in freshwater, intertidal wetland, and marine sediments by using millions of Illumina tags. Appl Environ Microbiol 78:8264-8271

*Wei G, Li M, Li F, Li H, Gao Z (2016) Distinct distribution patterns of prokaryotes between sediment and water in the Yellow River estuary. Appl Microbiol Biotechnol 100: 9683-9697

*Whitfield AK, Elliott M, Basset A, Blaber SJM, West RJ (2012) Paradigms in estuarine ecology - a review of the Remane diagram with a suggested revised model for estuaries. Estuar Coast Shelf Sci 97:78-90

Whittaker RH (1972) Evolution and measurement of species diversity. Taxon 21:213-251

* Wilms R, Sass H, Köpke B, Köster J, Cypionka H, Engelen B (2006) Specific bacterial, archaeal, and eukaryotic communities in tidal-flat sediments along a vertical profile of several meters. Appl Environ Microbiol 72:2756-2764

Z Zhang L, Gao G, Tang X, Shao K (2014) Can the freshwater bacterial communities shift to the 'marine like' taxa? J Basic Microbiol 54:1264-1272

* Zhang W, Bougouffa S, Wang Y, Lee OO and others (2014) Toward understanding the dynamics of microbial communities in an estuarine system. PLOS ONE 9:e94449

K Zinger L, Amaral-Zettler LA, Fuhrman JA, Horner-Devine MC and others (2011) Global patterns of bacterial betadiversity in seafloor and seawater ecosystems. PLOS ONE 6:e24570

Submitted: August 21, 2017; Accepted: April 27, 2018

Proofs received from author(s): June 26, 2018 